\title{
DEVELOPMENT OF QUALITY MANAGEMENT SYSTEM UNDER ISO 9001:2015 AND JOINT INSPECTION GROUP (JIG) FOR AVIATION FUELLING SERVICE
}

\author{
Kanon Ruamchat ${ }^{1}$, Natcha Thawesaengskulthai ${ }^{2}$, Chaipong Pongpanich ${ }^{3}$ \\ 1 Technopreneurship and Innovation Management, Graduate School, Chulalongkorn University, Bangkok, Thailand \\ ${ }^{2}$ Department of Industrial Engineering, Faculty of Engineering, Chulalongkorn University, Bangkok, Thailand \\ ${ }^{3}$ Sasin Graduate Institute of Business Administration of Chulalongkorn University, Bangkok, Thailand
}

Corresponding author:

Natcha Thawesaengskulthai

Department of Industrial Engineering

Faculty of Engineering

Chulalongkorn University

254 Phayathai Road, Pathumwan, Bangkok, Thailand 10330

phone: 662-218-6822

e-mail: natcha.t@chula.ac.th

Received: 22 September 2016 Accepted: 10 April 2017

\section{Abstract}

The Joint Inspection Group (JIG) standard for aviation fuel quality management assists in the operational process and maintenance of aviation fuel from its point of origin and through distribution systems to airports. Currently, problems arise as the JIG standard and quality management in aviation fuel are isolated and have independent procedures. Merging the JIG standards with ISO 9001:2015 can override original JIG's philosophy by connecting all quality assessment, and management parties involved, throughout the supply chain. This integration can harmonize auditing tasks, focusing on risk/opportunity, and continue quality improvement focus. This paper proposes a development of quality management system (QMS) under ISO 9001:2015 for aviation fuelling service in a systematic way. The content and critical success factors of ISO 9001:2015 and JIG standards were studied. The beneficial synergies, similarities, and logical linkages between both standards are identified. This QMS was developed in the largest petroleum company in Thailand and 60 selected experts were surveyed, with a response rate of $88.3 \%$, for their agreement on integrated criteria. Two external quality auditors, who have ISO 9001 and JIG expertise, were interviewed to modify our initial proposed QMS. The final QMS was implemented in the into-plane fuelling services as the first phase of this implementation. Results of framework implementation are discussed in a case study. There are mutual benefits resulting from the integration of JIG and ISO 9001:2015 standards. This QMS provides a unified process for quality management practices, and enhances the effectiveness of risk evaluation as well as the opportunity for continued quality improvement. It facilitates the identification of ISO 9001:2015 requirements and establishes relationships between the roles of JIG standard and the clauses of ISO 9001:2015. The first experience from five airports as the pilot study of proposed QMS implementation minimized conflicts and duplications between JIG and ISO 9001:2015 standards, reduced the number of into-plane fuelling service incidents reported, such as oil spill, machine stoppage, re-inspections, and recall costs.

KEYWORDS

ISO 9001, QMS, integration system, quality assurance, aviation fuelling service.

\section{Introduction}

The aviation fuelling service industry, complex and advanced systems are constantly being developed and updated. Despite system improvements and advances in technology, the organizational and human factors that interact with those systems remain the fundamental causes of most fuelling accidents $[1,2]$. In order to minimize such accidents, an integration of quality management system (QMS) 
and safety management system (SMS) is currently being viewed as an effective, systematic management model [3].

SMS monitors safety performance, identifies quality gaps, evaluates related risks, and manages the risks effectively. However, QMS concentrates on compliance with regulations and requirements in order to satisfy customer expectations and contractual obligations. QMS focuses on products and services with certain levels of quality, consistency, and satisfaction, while SMS focuses on safety performance to control the risks occurring during the processes or services [4]. In general, QMS and SMS have many similarities but are used in different roles and have different expected results. QMS is focused on products, services, and customer satisfaction. However, SMS is focused on human, and organizational safety $[4,5]$.

In addition to QMS, aviation fuelling quality management utilizes safety and reliability engineering to identify failure conditions and improve failure rates. The failure of any critical component in the process may result in unsafe conditions. Note that, aviation fuelling and storage at the depot are accompanied by attendant hazards which must be mitigated to acceptable levels. Issues can occur from either the fuel sources at the depot, fuel transportation onsite, or a fuel hydrant system. The primary risk is unintended ignition of fuel vapour, which can occur by a single spark. Escaping fuel vapours, and the risk of ignition, often result from spillage arising from procedural errors, leaks, aircraft tank venting, or failure of pressurized defuel lines or their couplings. For example, in 2001, a Boeing 777-236 was substantially damaged, and a refuelling operative was killed during a ground fire at Denver International Airport. The fire started when the airplane was parked at the gate unloading passengers and was being refuelled at the under-wing refuelling panel. The fire broke out following the failure of a refuelling coupling under pressure as a result of improper attachment [6].

Fuel systems differ greatly among aircraft due to the relative size and complexity of the aircraft in which they are installed. In the most basic form, a fuel system will consist of a single gravity feed fuel tank with the associated fuel line connecting it to the aircraft engine. In a modern, multi-engine passenger or cargo aircraft, the fuel system is likely to consist of multiple fuel tanks which may be located in the wing or the fuselage (or both). Each tank may be equipped with internal fuel pumps and associated valves and plumbing to feed the engines, allow for refuelling and defueling, and isolate the individual tanks [7]. Figure 1 presents the schematic for the supply and distribution chain from refinery to aircraft.
Risk of contamination is another critical fuel system issue. The primary types of contamination are water, particulate, and microbiological material. In addition, contamination can occur from other fuel grades and chemicals that may be in multi-product transport systems. The fuel may also be rendered off-specification by either under-dosing/overdosing of approved additives, using an incorrect additive, or from product testing issues not limited to, but including, poor sampling, incorrect test procedures, and uncalibrated laboratory equipment. These issues can occur at various points in the supply chain [8].

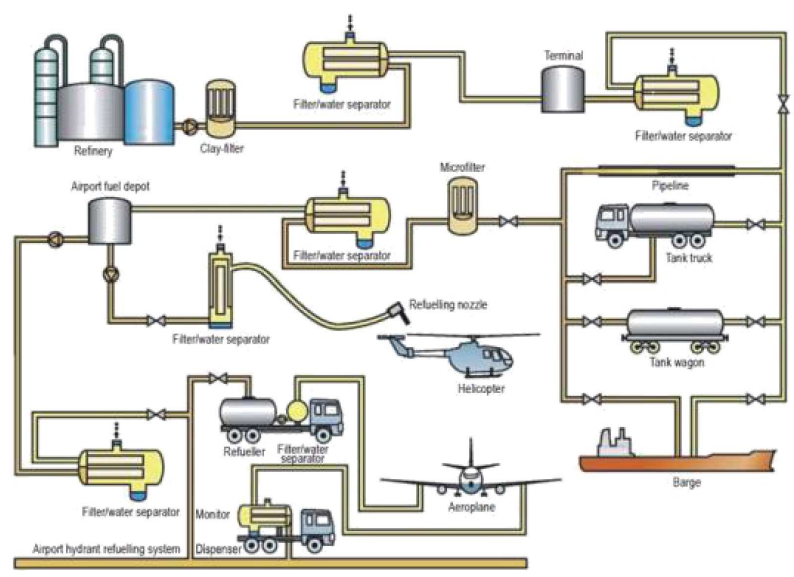

Fig. 1. Schematic for the supply and distribution chian from refinery to aircraft [8].

Most airports have already established QMS and SMS programs such as Joint Inspection Group, or JIG standard. Identification of hazards associated with organizational factors, including human performance within the organization is a paradigm shift to systematic safety management. Moreover, improving the fuelling services to a zero accident goal, QMS should be implemented and integrated with SMS. SMS is specially designed for aviation fuelling system programs, while QMS is a generic and non-industry specific [9]. This QMS is similar to the previous extension of ISO 9001 to specific industries, such as ISO/TS 16949 for automotive production, ISO/TS 29001 for petroleum, petrochemical and natural gas industries, ISO 13485 for medical devices, ISO/IEC 90003 for software engineering, ISO 17582 for electoral organizations, and ISO 18091 for local government.

Therefore, this paper aims primarily to develop a QMS under ISO 9001: 2015 with JIG standard (SMS) to improve aviation fuelling service. The purpose of this development includes expanding risk management to the operational parts, integrating the different management systems into a unique system, 
connecting and aligning the QMS with the best practices provided by JIG standards, and implementing the integration of ISO 9001: 2015 and JIG standards into five Thai airports as the pilot study of the initial framework implementation. In addition, as the fuelling service quality is our major focus, our proposed framework covers fuel systems from the depot to into-plane fuelling services. This paper explains why the airports should begin to adopt the integrated QMS and SMS framework in order to manage risks with a systematic management approach and to prevent aircraft accidents caused by improper or poor quality fuelling services.

\section{Theoretical background}

This section is composed of three parts; ISO 9001:2015 components and its critical success factors, JIG standard requirements, and a review of the standard integration approach.

\section{ISO 9001:2015 components}

ISO 9001 the most extensive international standard for the establishment, and maintenance of quality management systems due to its focus on customers through leadership, teamwork, process approach, systems approach to management, continued improvement, and information based decisionmaking. ISO 9001 is applicable to organizations of all types. It covers the basic processes within the organization; it also provides certain actions for control over processes and management. QMS according to ISO 9001 standard is currently used throughout the world and increased certification of the system insures the quality of products or services. Today, the aviation industry is busy assessing the impact of ISO 9001:2015, and updating quality management systems to meet the revision requirements. ISO 9001:2015 is less product-oriented than previous versions; ISO 9001:2008 [10]. Therefore, this can be generically applied to services as well as products that benefit the aviation fuelling services and quality management. The major change in the ISO 9001:2015 standard is to establish a systematic approach to risk by promoting risk-based thinking. Risk management is considered throughout the QMS. The emphasis on risk management in the revised standard provides the necessary balance between cost, schedule, technical, safety, and regulatory compliance. QMS outlined by ISO 9001 reinforces the quality control process and business management as the major change in the 2015 version [11]. The high level structure, or clauses, of ISO 9001:2015 is shown in Table 1.
Table 1

High level structure of ISO 9001:2015 [11].

\begin{tabular}{c|c|c}
\hline Clauses no. & Description & Purpose \\
\hline 1 & Scope & Overview \\
\hline 2 & Normative references & \multirow{2}{*}{ References } \\
\hline 3 & Terms and definitions & \\
\hline 4 & Context of organization & \\
\hline 5 & Leadership & \multirow{2}{*}{ Requirements } \\
\hline 6 & Planning & \\
\hline 7 & Support & \\
\hline 8 & Operations & \\
\hline 9 & Performance and evaluation & \\
\hline 10 & Improvements &
\end{tabular}

The number of companies obtaining ISO 9001 certification has been increasing over the years [12] because of the extensive benefits of ISO 9001:2015 implementation and its maintenance, including market expansion [13], improved product and service quality [14] cost reduction and financial benefits [15], improved customer satisfaction and confidence [16], enhanced employee involvement and morale [13], ontime product delivery and improved product performance [17], and systematic organization [18]. However, there were a few criticisms published of ISO 90001 drawbacks including; increased bureaucracy and documentation [19], excessive implementation costs that may not be unaffordable for small and medium-size enterprises (SMEs) [20], and that the standard is too generic requiring extension to specific industries [9]. The most important factors of implementing ISO 9001 include; management, training, resources, and customers-focus [21].

\section{Joint inspection group (JIG) standard}

The JIG standard for Aviation fuel quality control and operating procedures consists of internationally agreed upon procedures for handling aviation fuel at airports and upstream aviation fuel facilities. The standard includes recommended practices for fuel sampling and testing, depot, hydrant, and fuelling vehicle design features, and procedures for storage and delivery of aviation fuel to aircraft. Figure 2, shown below, maps the JIG standards to the aviation fuel supply chain which is shown as follows:

- EI/JIG standard 1530 defines quality assurance requirements for the manufacture, storage and distribution of aviation fuels to airport;

- JIG 1 issue 12 is the aviation fuel quality control and operating standard for into-plan fuelling service [22];

- JIG 2 issue 12 is the aviation fuel quality control and operating standard for airport depots and hydrants [23]. 


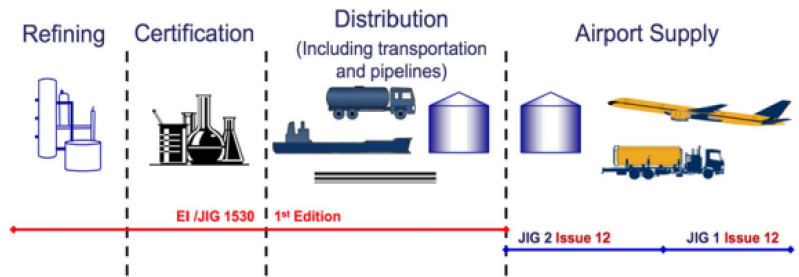

Fig. 2. Overview of JIG standards mapped with aviation fuelling supply chain.

EI/JIG 1530 1st edition was exhibited on October 2013, and JIG 1 and 2 issue 12 were exhibited on January 2016. In this paper, JIG 1 and 2 issue 2 have been applied for development of the QMS, therefore, the discussion of JIG 1 and 2 are presented in this section. Both JIG 1 and 2 Standards contain three main parts; quality control, maintenance, and accident/incident reporting. The shared goals of JIG standards include zero breakdown of fuelling and depot storage equipment, zero defects, and zero accidents. The JIG standard is a comprehensive set of quality control and maintenance practices. Along with maintenance, JIG standards facilitate airport management with an emphasis on quality, safety and productivity, which results in an overall performance enchantment of fuelling services. Therefore, JIG standards involves four main parties; fuelling operator or staffs, internal and external inspectors, airport management, and fuel suppliers [22, 23].

\section{ISO 9001 Standards Integration}

The integration of ISO 9001 standards with other standards has been reviewed and conclude with the connection, or integration, into four angles; principlebased connection, elements and technique based connections, connections though award-based quality frameworks, and plan-do-check-act (PDCA) based connection [24]. The principle-based connection is to investigate the standard principle and draw its con- nection. This can help the developer to determine the shared objectives between two standards [25]. The element-based connection is to integrate the elements of standards, identifying the compatibility, confliction, and similarity [26]. The connection through award-based quality framework is similar to the principle-based connection, however, the link based on the award perspective (i.e. Malcolm Baldrige National Quality Award) is to create the shared principles [27]. Finally, the basics of PDCA in ISO 9001 is to portray the clause of QMS requirements [28]. In terms of the development of a QMS under ISO 9001:2015 and JIG standard, the first two angles were selected; principle-based connection to define the shared objectives, and elements-based connection to find the similarity and capability between these standards, and to illustrate into the conceptual model using the PDCA connection.

\section{Methodology}

Research methodology in this study is divided into two parallel phases as presented in Fig. 3. The first phase is to integrating ISO 9001:2015 and JIG standards development and implementation. The second phase is the evaluation process for: 1) validation of the proposed QMS, and 2) feedback analysis from the framework implementation. The principles and elements of ISO 9001: 2015 and JIG 1 and 2 issue 12 standards were extracted. The shared principles were formed as the unique principle for this integration (result in Table 2). In addition, the elements of ISO 9001: 2015 (clause 4-10) were set and matched to the elements of JIG standards (QC, maintenance, and monitoring). The similarity of elements was integrated into single element. The elements of ISO 9001:2015 which is not related to the aviation fuel quality management was eliminated (integration results shows in Table 3). However, our initial principle

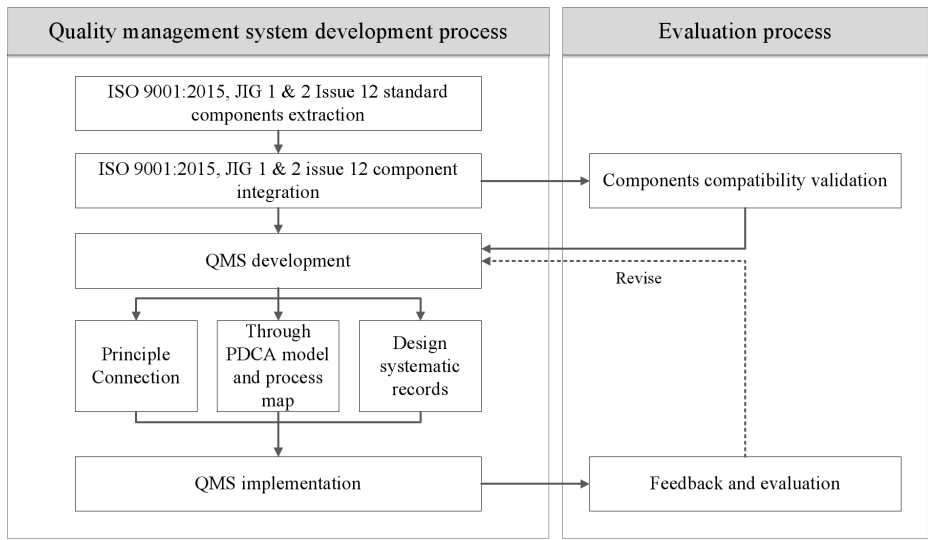

Fig. 3. Research methodology is divided into two types; (1) QMS development process, and (2) evaluation process. 
and element integration was checked by 60 employees who experiences of ISO 9001 and JIG standards and have been working in aviation fuel services in Thai airports more than 5 years using survey instruments, and two external quality management experts utilizing focus group interviews. A response rate was $88.3 \%$ due to the participants' available time.

The survey consists of two parts. We selected the focus group to answer the survey so that the demographic survey was eliminated as the survey should be conducted as simply as possible. There were 60 selected employees were surveyed, with a response rate of $88.3 \%$. The first part of survey determines the relationship between ISO 9001:2015 and JIG 1 and 2 standards. This questionnaire aims to investigate the possibility of integration between these standards based on the operative experiences. The options consist of 1) separate implementation of ISO 9001:2015 and JIG 1 and 2 standards, 2) ISO 9001:2015 merges JIG 1 and 2 standards, and 3) integrating ISO 9001:2015 and JIG 1 and 2 standards. In addition, the respondents were then asked to indicate the possibility using "yes/no" questions in integrating ISO 9001:2015 elements with JIG standards. The degree of difficulties were included in the questionnaires using a scale from 1 to 5, which denote "easy" to "difficult" range. The second parts allow the participants to evaluate the principle and elements compatibility of our initial match. Finally, the survey data collection and analysis with our proposed QMS model were discussed with two external quality management experts. At this stage, the final QMS was concluded, then we defined the conceptual models though PDCA models (see Fig. 5) and the process procedures using a turtle diagram (see Fig. 6), which is a quality tool used to visually display process characteristics.

Finally, the QMS was implemented during May 2016 at five selected airports located in Thailand. Note that, the internal auditing process has routinely taken weekly. The historical number of incidents has been collected for five years. The comparison between the average of number of incident in 2015 and the number of incidents detected in May 2016 is performed. The feedback was collected from two internal auditors though the short second survey to evaluate the fuelling service improvement for each airports using a scale of 1 "not improve" to 5 "very improve".

\section{Results}

\section{Component compatibilities}

Figure 4 presents the survey feedback of the relationship between ISO 9001:2015 and JIG 1 and 2 issue 12 from fuelling operative senior staffs familiar with ISO 9001 and JIG standards for more than 5 years. It shows that $9.4 \%$ of respondents do not agree with integrating these two standards. They found that ISO 9001 is too generic and connects all stakeholders, potentially causing difficulty of implementation. $22.6 \%$ of responses agree with this difference and recommended merging ISO 9001:2015 and JIG standards. However, about $67 \%$ of overall respondents agreed and saw the benefit of this integration in improving the current procedures to cope with continue quality improvement. In addition, Fig. 5 presents the possibility percentage and difficulty level of integrating ISO 9001:2015 with JIG standards for each ISO 9001:2015 elements.

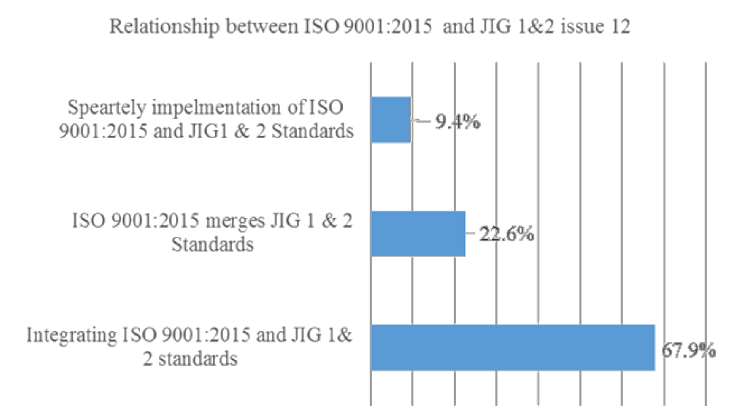

Fig. 4. The relationship between ISO 9001: 2015 and JIG 1 and 2 issue 12 based on the survey.

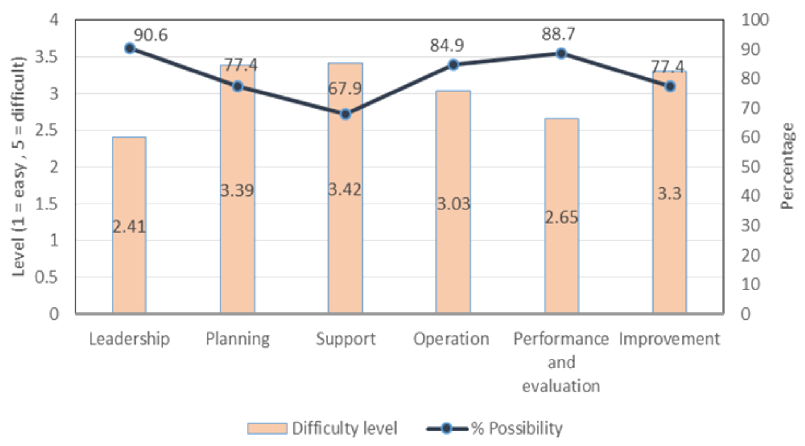

Fig. 5. Possibility percentage (\%) and difficulty level of integrating ISO 9001:2015 with JIG standards (range 1-5).

\section{QMS development}

Table 2 shows the final principle integration between ISO 9001 and JIG standard. The JIG standard objectives to three main principles of ISO 9001:2015; including improvement, process approach, and engagement and competence of people. As a result, the QMS focuses on the process approach, continued quality improvement, and engagement and competence of people as its first priority. Table 3 presents the final elements of standards integration (after survey and revised by two experts in quality management system in petroleum industry). 
Table 2

Principles-based integration between ISO 9001:2015 and JIG 1 and 2.

\begin{tabular}{|c|c|c|}
\hline ISO 9001: 2015 & JIG 1 and 2 issue 12 & Principle-based connection \\
\hline $\begin{array}{l}\text { - Customer focus } \\
\text { - Leadership } \\
\text { - Engagement and competence of people } \\
\text { - Process approach } \\
\text { - Improvement } \\
\text { - Informed decision making } \\
\text { - Relationship management }\end{array}$ & $\begin{array}{l}\text { - Planned maintenance } \\
\text { - Quality maintenance } \\
\text { - Education and training } \\
\text { - Safety, health, and environment } \\
\text { - Development management }\end{array}$ & $\begin{array}{l}\text { Improvement } \\
\text { - Development management } \\
\text { Process approach } \\
\text { - Planned maintenance } \\
\text { - Quality maintenance } \\
\text { - Focus in Safety, health, and environment } \\
\text { Engagement and competence of people } \\
\text { - Education and training } \\
\text { - Development management }\end{array}$ \\
\hline
\end{tabular}

Table 3

Element-based integration between ISO 9001:2015 and JIG 1 and 2 standards.

\begin{tabular}{|c|c|c|c|c|}
\hline Dimension & ISO 9001:2015 & JIG 1 issue 12 & JIG 2 issue 12 & Integration \\
\hline $\begin{array}{c}\text { Context } \\
\text { of } \\
\text { organization }\end{array}$ & $\begin{array}{l}\text { 4.1 Understanding } \\
\text { organization context } \\
\text { 4.2 Understanding } \\
\text { interested parties } \\
\text { 4.3 Scope } \\
\text { 4.4 QMS }\end{array}$ & \multirow{2}{*}{$\begin{array}{l}1 \text { Purpose, scope, } \\
\text { application, staff } \\
\text { responsibilities, } \\
\text { and inspection } \\
\text { requirement }\end{array}$} & \multirow{2}{*}{$\begin{array}{l}1 \text { Purpose, scope, } \\
\text { application, staff } \\
\text { responsibilities, } \\
\text { and inspection } \\
\text { requirement }\end{array}$} & $\begin{array}{l}\text { - } \text { Purpose } \\
\text { - Scope } \\
\text { - Application } \\
\text { - Staff responsibility } \\
\text { - Inspection } \\
\text { requirements } \\
\end{array}$ \\
\hline Leadership & $\begin{array}{l}5.1 \text { Leadership } \\
\text { and commitment } \\
5.2 \text { Policy } \\
5.3 \text { Organizational roles, } \\
\text { responsibilities } \\
\text { and authority }\end{array}$ & & & $\begin{array}{l}\text { - Leadership } \\
\text { and commitment } \\
\text { - Policy } \\
\text { - Organizational roles } \\
\text { - Authority }\end{array}$ \\
\hline Planning & $\begin{array}{l}\text { 6.1 Actions to address risks } \\
\text { and opportunities } \\
\text { 6.2 Quality objectives } \\
\text { and planning } \\
\text { 6.3 Planning of changes } \\
\end{array}$ & $\begin{array}{l}5 \text { Fuel quality control } \\
\text { requirement }\end{array}$ & $\begin{array}{l}10 \text { General operation } \\
\text { requirement } \\
\text { and maintenance }\end{array}$ & $\begin{array}{l}\text { - Actions to address } \\
\text { risks and opportunities } \\
\text { - Quality control } \\
\text { and planning } \\
\text { - Planning of changes } \\
\end{array}$ \\
\hline Support & $\begin{array}{l}\text { 7.1 Resources } \\
\text { 7.2 Competence } \\
\text { 7.3 Awareness } \\
7.4 \text { Communication } \\
\text { 7.5 Documented } \\
\quad \text { information }\end{array}$ & $\begin{array}{l}2 \text { Sampling and testing } \\
3 \text { Fuelling equipment } \\
\text { design features } \\
7 \text { Documentation }\end{array}$ & $\begin{array}{l}2 \text { Sampling and testing } \\
3 \text { Depot facilities } \\
\text { design features } \\
9 \text { Documentation }\end{array}$ & $\begin{array}{l}\text { - Resources (i.e. equipment, } \\
\text { depot, aircrafts, etc.) } \\
\text { - Quality control } \\
\text { and assurance results } \\
\text { (i.e. fuel sampling tests, } \\
\text { equipment tests) } \\
\text { - On-site incidents } \\
\text { and lesson learn } \\
\text { - Knowledge (i.e. stan- } \\
\text { dards, best practices } \\
\text { manual, training } \\
\text { documents, etc.) } \\
\text { - Communication plan } \\
\text { and log } \\
\text { - Activity log } \\
\text { - Service log } \\
\text { - Systematic records } \\
\end{array}$ \\
\hline Operation & $\begin{array}{l}\text { 8.1 Operational planning } \\
\text { and control } \\
\text { 8.2 Product and service } \\
\text { requirements } \\
\text { 8.3 Design } \\
\text { and development } \\
\text { 8.4 Control of externally } \\
\text { provided processes, } \\
\text { products and services } \\
\text { 8.5 Production } \\
\text { and service provision } \\
\text { 8.6 Release of products } \\
\text { and services } \\
\text { 8.7 Control of noncon- } \\
\text { forming outputs }\end{array}$ & $\begin{array}{l}6 \text { Fuelling operations } \\
8 \text { Health, safety, } \\
\text { security, environment, } \\
\text { training, and } \\
\text { emergency procedures }\end{array}$ & $\begin{array}{l}4 \text { Receipt procedures } \\
6 \text { Storage procedures } \\
7 \text { Produce release } \\
\text { for delivery } \\
\text { to into-plane fuelling } \\
\text { equipment } \\
11 \text { Health, safety, } \\
\text { security, environment } \\
\text { training, } \\
\text { and emergency } \\
\text { procedures }\end{array}$ & $\begin{array}{l}\text { - Best practices } \\
\text { of fuelling } \\
\text { and storage } \\
\text { (operational planning) } \\
\text { - Operational } \\
\text { requirements } \\
\text { (external control) } \\
\text { health, safety, } \\
\text { security, environment, } \\
\text { training, and } \\
\text { emergency } \\
\text { procedures } \\
\text { - Maintenance }\end{array}$ \\
\hline $\begin{array}{l}\text { Performance } \\
\text { and } \\
\text { evaluation }\end{array}$ & 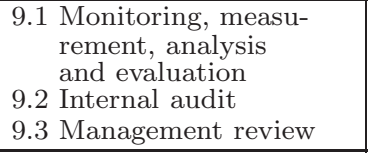 & $\begin{array}{l}4 \text { Maintenance } \\
\text { and testing } \\
\text { of fuelling equipment }\end{array}$ & 5 Quality control & $\begin{array}{l}\text { - Testing } \\
\text { - Quality control } \\
\text { - Monitoring } \\
\text { - Internal audit } \\
\text { - External audit }\end{array}$ \\
\hline Improvement & $\begin{array}{l}\text { 10.1 General } \\
10.2 \text { Nonconformity } \\
\text { and corrective action } \\
\text { 10.3 Continuous } \\
\text { improvement }\end{array}$ & $\mathrm{N} / \mathrm{A}$ & $\mathrm{N} / \mathrm{A}$ & $\begin{array}{l}\text { - Risk assessment } \\
\text { - Planning corrective/ } \\
\text { preventative action } \\
\text { - Continuous } \\
\text { improvement }\end{array}$ \\
\hline
\end{tabular}


After the elements, or components, of ISO 9001:2015 and JIG standards were integrated and merged, the conceptualization of QMS though the PDCA lens was developed and used to communicate during the framework implementation stage (see Fig. 5). All components are connected during the communication and backup with the resources and knowledge. There are two dimension of quality delivery; horizontal driven with satisfied aviation fuelling service, and vertical driven with continued quality improvement. The vertical driven applies a risk as- sessment that results in corrective and preventative actions based on a root-cause analysis. This new solution of actions must be added to the operational requirements, and updating the process procedures. For planning, the actions of addressing the risk and opportunity for improvement should be developed and driven by leadership. The systematic records are used to monitor performances.

In terms of the QMS implementation, the process approach has been created using the turtle diagram (see Fig. 6). The systematic document of this QMS

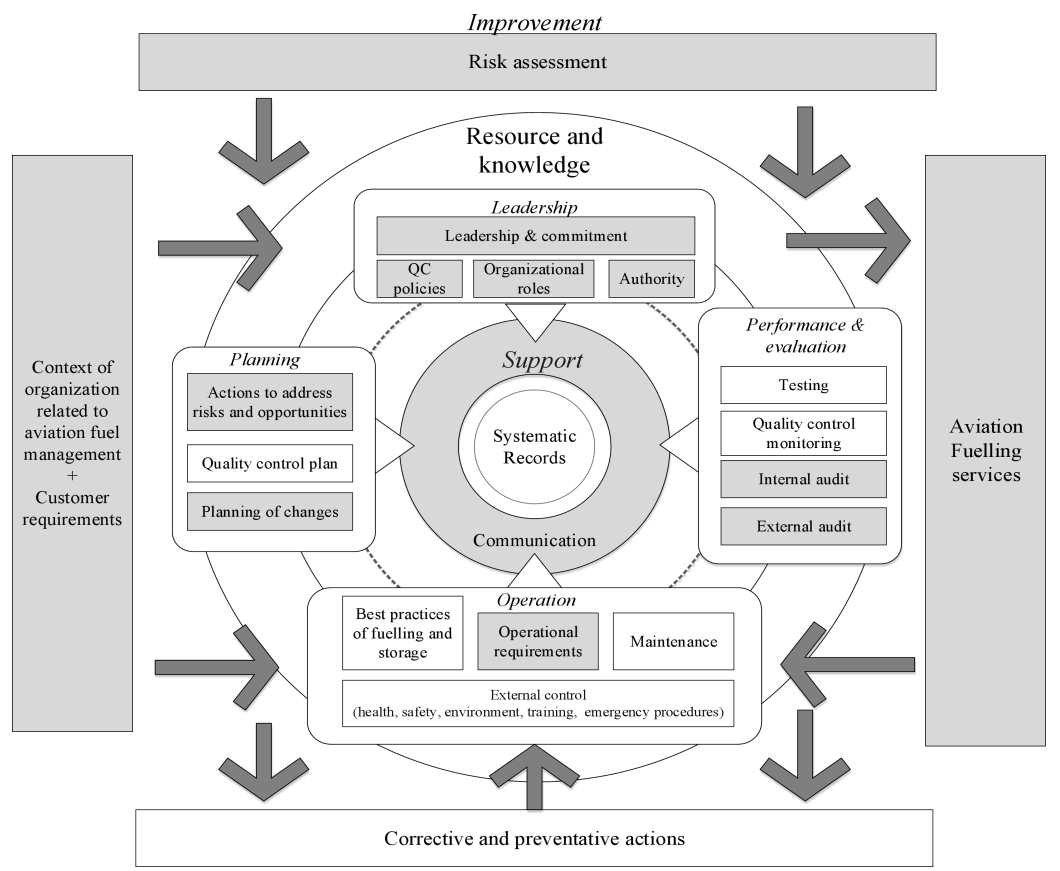

Fig. 6. Conceptual of QMS of ISO (grey colour) and JIG standards (white colour).

\begin{tabular}{|c|c|c|}
\hline Equipment & Process flow and implementation & Personal \& Competencies \\
\hline $\begin{array}{l}\text { - Testing and calibration } \\
\text { equipment } \\
\text { - Personal protective equipment }\end{array}$ & \multirow{6}{*}{$\begin{array}{l}\text { - Testing and sampling } \\
\text { - Testing standard of fuelling } \\
\text { equipment } \\
\text { - Maintenance standard } \\
\text { - Acceptance criteria } \\
\text { - Inspector qualification } \\
\text { - Equipment commissioning and } \\
\text { calibration } \\
\text { - Identification of } \\
\text { - Routine inspection } \\
\text { - Storage inspection } \\
\text { - Product release for } \\
\text { delivery } \\
\text { to into-plan fuelling } \\
\text { equipment and hydrant } \\
\text { - Fuelling personnecl } \\
\text { inspection } \\
\text { - Vehicle inspection } \\
\text { - Documented procedure } \\
\text { - Control of measuring } \\
\text { equipment and testing } \\
\text { - Calibration or verification plan } \\
\text { - Calibration records and } \\
\text { acceptance criteria } \\
\text { - Identify of measurement status } \\
\text { - Corrective \& presentation } \\
\text { actions }\end{array}$} & $\begin{array}{l}\text { - Inspector qualification } \\
\text { - Special training / On-site } \\
\text { training } \\
\text { - Equipment calibration } \\
\text { programme } \\
\text { - Skill assessment programme }\end{array}$ \\
\hline \multirow{2}{*}{$\begin{array}{l}\text { - Fuel quality check } \\
\text { - Receives fuel into depot } \\
\text { - Into-plane fuelling services } \\
\text { - Fuel transportation } \\
\text { - Equipment calibration } \\
\text { - Heath and safety control }\end{array}$} & & Output \\
\hline & & \multirow{2}{*}{$\begin{array}{l}\text { - Receives fuel then stores in } \\
\text { depot } \\
\text { - Into-plane fuelling service to } \\
\text { customers } \\
\text { - Preventative maintenance } \\
\text { activities }\end{array}$} \\
\hline Documentation/methods & & \\
\hline \multirow{2}{*}{$\begin{array}{l}\text { - Fuelling equipment design } \\
\text { features } \\
\text { - Fuel quality control } \\
\text { requirements } \\
\text { - Depot facilities and design } \\
\text { features } \\
\text { - Quality control requirements } \\
\text { - Receipt procedures } \\
\text { - Maintenance procedures } \\
\text { - General operating } \\
\text { requirements }\end{array}$} & & Criteria : objective \& Targets \\
\hline & & $\begin{array}{l}\text { - No of incident / accident } \\
\text { - No of inspector complaint } \\
\text { - No of change of fuel grade } \\
\text { poor services | time delay) }\end{array}$ \\
\hline
\end{tabular}

Fig. 7. Process approach using turtle diagram (through auditor point of view). 
is presented into four categories; policy and procedure (Table 4), quality control (Table 5), main- tenance (Table 6), and quality improvement (Table 7 ).

Table 4

Systematic records of QMS (policy and procedures).

\begin{tabular}{c|l}
\hline Standards & \multicolumn{1}{c}{ Systematic records } \\
\hline & $\begin{array}{l}\text { - Scope of quality management system (clause 4.3) } \\
\text { - Quality policy and objectives (clause 5.2 and 6.2) } \\
\text { - Internal audit and procedure (clause 9.2) } \\
\text { - Results of management review (clause 9.3) } \\
\text { - Procedure for monitoring customer satisfaction (clause 9.1.2) }\end{array}$ \\
\hline JIG 1 & $\begin{array}{l}\text { - Purpose, scope, application and inspection equipment (chapter 1) } \\
\text { - Health, safety, security, environment, training, and emergency procedures } \\
\text { (chapter 8 in JIG 1, and chapter 11 in JIG 2) } \\
\text { - JIG inspection programme }\end{array}$ \\
\hline
\end{tabular}

Table 5

Systematic records of QMS (Quality control).

\begin{tabular}{|c|c|}
\hline Standards & Systematic records \\
\hline ISO 9001:2015 & $\begin{array}{l}\text { - Monitoring and measuring equipment calibration records (clause 7.1.5.1) } \\
\text { - Monitoring and measurement results (clause 9.1.1) } \\
\text { - Fuelling provision change control records (clause 8.5.6) } \\
\text { - Record of conformity of fuels with acceptance criteria (clause 8.6) } \\
\text { - Characteristic of fuel products (clause 8.5.1) } \\
\text { - Record of conformity of fuelling services with acceptance criteria (clause 8.6) }\end{array}$ \\
\hline JIG 1 & $\begin{array}{l}\text { - Daily water drain record } \\
\text { - Filter membrane test results including membranes } \\
\text { - Fuel sample records } \\
\text { - Filtration equipment: differential pressure record and graphs } \\
\text { - Change of fuel grade - selective setting check record }\end{array}$ \\
\hline JIG 2 & $\begin{array}{l}\text { - Daily product dips, tank contents and water checks, including date/time } \\
\text { - Detail of incoming consignments with reference to Refinery Certificate of Quality or Certificate } \\
\text { of Analysis and release certificate, quality, including data and time } \\
\text { - Receipt tank detail, setting and release checks } \\
\text { - Product deliveries and transfers including date/time when tanks put in service } \\
\text { - Refinery certificate of quality or certificate of analysis } \\
\text { and release certificates covering incoming consignments } \\
\text { - Recertification and periodic test certificates } \\
\text { - Hydrant pit use of low point flushing } \\
\text { - Filter membrane test records } \\
\text { - Filter sump drains }\end{array}$ \\
\hline
\end{tabular}

Table 6

Systematic records of QMS (Maintenance).

\begin{tabular}{|c|c|}
\hline Standards & Systematic records \\
\hline ISO 9001:2015 & $\begin{array}{l}\text { - Monitoring and measuring equipment calibration records (clause 7.1.5.1) } \\
\text { - Monitoring and measurement results (clause 9.1.1) } \\
\text { - Fuelling provision change control records (clause 8.5.6) } \\
\text { - Record of conformity of fuels with acceptance criteria (clause 8.6) }\end{array}$ \\
\hline JIG 1 & $\begin{array}{l}\text { - Logbook to record work carried out on each items of equipment } \\
\text { - Mobile equipment serviceability checks } \\
\text { - Hose stowage/brake interlocks, Emergency/engine stops } \\
\text { - Pressure. Surge control systems and deadman checks } \\
\text { - Hose inspection and testing, Meter test record } \\
\text { - Pressure and vacuum gauge test record } \\
\text { - Coupler inspection and repair record } \\
\text { - Nozzle inspection and repair record } \\
\text { - Fuller tank inspection and cleaning record } \\
\text { - Filtration equipment: inspection and maintenance records } \\
\text { - Hose-end strainers inspection/replacement record } \\
\text { - Fire extinguisher check record } \\
\text { - Equipment calibration programme }\end{array}$ \\
\hline JIG 2 & $\begin{array}{l}\text { - Storage take details and tank inspection and cleaning records } \\
\text { - Micro filter and filter separator differential pressure graphs and inspection and maintenance records } \\
\text { - Hydrant pit cleaning and checking of pit components } \\
\text { - Hose inspection and testing } \\
\text { - Details and dates of all maintenance work } \\
\text { - Equipment calibration programme }\end{array}$ \\
\hline
\end{tabular}


Table 7

Systematic records of QMS (Quality improvement).

\begin{tabular}{|c|c|}
\hline Standards & Systematic records \\
\hline ISO 9001:2015 & $\begin{array}{l}\text { Procedure for addressing risks and opportunities (clause 6.1) } \\
\text { Procedure for management review (clause 9.3) } \\
\text { Procedure for fuelling services provision (clause 8.3) } \\
\text { Procedure of competence, training and awareness (clause 7.1.2,7.2 and 7.3) } \\
\text { Record of training, skills, experiences and qualification (clause 7.2) } \\
\text { Records of development control and output (clause 8.3.4 and 8.3.6) } \\
\text { Records about property (clause 8.5.3) } \\
\text { Procedure for corrective actions (clause 10.2) }\end{array}$ \\
\hline JIG 1 & Incident or accident report (chapter 7.5 in JIG 1, chapter 9.5 in JIG 2) \\
\hline JIG 2 & Routine test frequencies \\
\hline
\end{tabular}

Table 8

Report of number of incidents that assessed by internal auditors (weekly visit) and the performance improvement though internal auditors' point of view.

\begin{tabular}{c|c|c|c|c|c}
\hline Site & $\begin{array}{c}\text { Average } \\
\text { number } \\
\text { of incident } \\
\text { in 2015 } \\
\text { (monthly) }\end{array}$ & $\begin{array}{c}\text { Number } \\
\text { of incidents } \\
\text { detected } \\
\text { in May 2016 } \\
\text { implementation) }\end{array}$ & $\begin{array}{c}\text { Number } \\
\text { of fuelling } \\
\text { services } \\
\text { in May 2016 }\end{array}$ & $\begin{array}{c}\text { Percentage } \\
\text { of number } \\
\text { incident } \\
\text { reduction }\end{array}$ & $\begin{array}{c}\text { Performance } \\
\text { evaluation feedback } \\
\text { from internal auditors } \\
\text { (1 - not at all improved, } \\
5-\text { very improved) }\end{array}$ \\
\hline Airport 1 & 7.4 & 3 & 5,574 & $59.5 \%$ & 4 \\
\hline Airport 2 & 5.6 & 3 & 481 & $46.4 \%$ & 3.5 \\
\hline Airport 3 & 6.1 & 4 & 182 & $34.4 \%$ & 3 \\
\hline Airport 4 & 4.8 & 1 & 1,236 & $79.2 \%$ & \\
\hline Airport 5 & 5.3 & 5 & 155 & $5.7 \%$ & \\
\hline Average & 5.8 & 3 & $1,868.3$ & $45.2 \%$ & 2.5 \\
\hline
\end{tabular}

\section{QMS Implementation (pilot study)}

The proposed QMS has been implemented in five randomly selected airports located in Thailand. Table 8 shows the comparison between the proposed QMS and JIG standard alone. The indicators of evaluation contains two matrices: 1) number of incidents before and after the QMS implementation, and 2) feedback from internal auditors. The data was collected during May 2016. The average number of monthly incidents across five airport in 2015 was 5.8 times. After the new QMS was implemented, the average number of monthly incident reduces to 3 times ( $45.2 \%$ reduction) with average number of 1,868.3 fuelling services. The feedback from two internal auditors indicated that the new QMS under ISO 9001:2015 and JIG standards can improve the aviation fuel services with level of 3.5 (Natural to somewhat improved).

\section{Conclusions}

The Joint Inspection Group (JIG) standard for aviation fuel quality management assists in the operational process and maintenance of aviation fuel from its point of origin and through distribu- tion systems to airports. Currently, problems arise as the JIG standard and quality management in aviation fuel are isolated. Merging the JIG standards with ISO 9001:2015 can override original JIG's philosophy by connecting all quality assessment, and management parties involved, throughout the supply chain. The content and critical success factors of ISO 9001:2015 and JIG standards were studied. The beneficial synergies, similarities, and logical linkages between both standards are identified. The QMS was developed through the principle-based integration, element-based integration, and systematic records. First stage of survey to identify the possibility of integration found that $67.9 \%$ agreed. This QMS was initial implemented into five selected airport located in Thailand. The feedback from internal auditors as well as the indicator of average number of monthly incidents detected were used for evaluating this QMS. The results showed that the new QMS reduced the average number of monthly incidents by $45.2 \%$ in five airports. The internal auditors' feedback was positive with natural to somewhat improved with the new QMS compared to the JIG standard alone.

The authors gratefully acknowledge funding support from the 90th Anniversary of Chulalongkorn University, Rachadapisek Sompote Fund. 


\section{References}

[1] Oster C.V., Strong J.S., Zorn C.K., Analyzing aviation safety: problems, challenges, opportunities, Research in Transportation Economics, 43, 148-164, 2013.

[2] Reason J.T., Reason J.T., Managing the risks of organizational accidents, Ashgate Aldershot, 1997.

[3] Jørgensen T.H., Remmen A., Mellado M.D., Integrated management systems - three different levels of integration, Journal of cleaner production, 14, 713-722, 2006.

[4] Lee W.K., Kim S.J., Roles of Safety Management System (SMS) in Aircraft Development, International Journal of Aeronautical and Space Sciences, 16, 451-462, 2015.

[5] Müller R., Wittmer A., Drax C., Aviation Risk and Safety Management, 2014.

[6] Brady T., The Aircraft Accident Investigation That Never Was, Journal of Aviation/Aerospace Education \& Research, 23, 1, 2014.

[7] Langton R., Clark C., Hewitt M., Richards L., Aircraft fuel systems, Wiley Online Library, 2009.

[8] ICAO 2012, Doc 9977, Manual on Civil Aviation Jet Fuel Supply, First Ed. 2012, International Civil Aviation Organization, 2012.

[9] Mak B.L., ISO certification in the tour operator sector, International Journal of Contemporary Hospitality Management, 23, 115-130, 2011.

[10] Fonseca L.M., From Quality Gurus and TQM to ISO 9001: 2015: a review of several quality paths, International Journal for Quality Research (IJQR), 9, 167-180, 2015.

[11] Palmes P.C., ISO 9001: 2015 transition starts with top management, 2015.

[12] Psomas E.L., Fotopoulos C.V., Kafetzopoulos D.P., Critical factors for effective implementation of ISO 9001 in SME service companies, Managing Service Quality: An International Journal, 20, 440-457, 2010 .

[13] Zeng S., Tian P., Tam C., Overcoming barriers to sustainable implementation of the ISO 9001 system, Managerial Auditing Journal, 22, 244-254, 2007.

[14] Ab Wahid R., Corner J., Critical success factors and problems in ISO 9000 maintenance, International Journal of Quality \& Reliability Management, 26, 881-893, 2009.

[15] Rusjan B., Alic M., Capitalising on ISO 9001 benefits for strategic results, International Journal of Quality \& Reliability Management, 27, 756-778, 2010.
[16] Sampaio P., Saraiva P., Guimarães Rodrigues A., ISO 9001 certification research: questions, answers and approaches, International Journal of Quality \& Reliability Management, 26, 38-58, 2009.

[17] Magd H., Curry A., An empirical analysis of management attitudes towards ISO 9001: 2000 in Egypt, The TQM Magazine, 15, 381-390, 2003.

[18] Gotzamani K.D., Tsiotras G.D., The true motives behind ISO 9000 certification: their effect on the overall certification benefits and long term contribution towards TQM, International Journal of Quality \& Reliability Management, 19, 151-169, 2002.

[19] Franceschini F., Galetto M., Maisano D., Mastrogiacomo L., A proposal of a new paradigm for national quality certification systems, International Journal of Quality \& Reliability Management, 28, 364-382, 2011.

[20] Boiral O., Managing with ISO systems: lessons from practice, Long Range Planning, 44, 197-220, 2011.

[21] Ismyrlis V., Moschidis O., Tsiotras G., Critical success factors examined in ISO 9001: 2008-certified Greek companies using multidimensional statistics, International Journal of Quality \& Reliability Management, 32, 114-131, 2015.

[22] Joint Inspection Group 2016a. JIG 1: Aviation Fuel Quality control \& Operating Standards for intoplane fuelling services, 2016.

[23] Joint Inspection Group 2016b. JIG 2: Aviation Fuel Quality Control \& Operating Standards for Airport Depots \& Hydrants, 2016.

[24] Sivaram N., Devadasan S., Sreenivasa C., Karthi S., Murugesh R., A literature review on the integration of total productive maintenance elements with ISO 9001 standard, International Journal of Productivity and Quality Management, 9, 281-308, 2012.

[25] Biazzo S., Bernardi G., Process management practices and quality systems standards: risks and opportunities of the new ISO 9001 certification, Business Process Management Journal, 9, 149-169, 2003.

[26] Psomas E.L., Fotopoulos C.V., A meta analysis of ISO 9001: 2000 research-findings and future research proposals, International Journal of Quality and Service Sciences, 1, 128-144, 2009.

[27] Seth D., Tripathi D., Relationship between TQM and TPM implementation factors and business performance of manufacturing industry in Indian context, International Journal of Quality \& Reliability Management, 22, 256-277, 2005.

[28] Ahmed S., Hassan M.Hj., Taha Z., TPM can go beyond maintenance: excerpt from a case implementation, Journal of Quality in Maintenance Engineering, 11, 19-42 2005. 